\title{
PENGARUH MODERNITAS SISWA DAN HASIL BELAJAR EKONOMI TERHADAP ECONOMIC LITERACY SISWA DI SMPN 3 PETERONGAN JOMBANG
}

\author{
Muizzatul Mutsaniah*
}

\begin{abstract}
The purpose of this study was to determine the effects of modernity and the student learning outcomes of the economy to student economic literacy. This study uses a quantitative approach to associative design. Population in this study was students of grade IX of 3rd State Junior High School of Peterongan, Jombang for academic year of 2012/2013 with total of 224 students. Sample was 144 students, selected by using simple random sampling. Data analysed using multiple regression analysis. The results showed that there is a significant effect of modernity students to student economic literacy. There is no significant effect of economic learning outcomes to student economic literacy. There are significant effects of modernity and student learning outcomes of the economy to student economic literacy.
\end{abstract}

Keywords: modernity of student, learning outcomes of the economy, economic literacy

\section{PENDAHULUAN}

$\mathrm{I}^{\mathrm{I}}$ mu ekonomi merupakan ilmu yang mempelajari upaya manusia dalam memenuhi kebutuhan/keinginan yang jumlahnya tidak terbatas dihadapkan dengan alat pemuas kebutuhan yang terbatas. Di Indonesia, pendidikan ekonomi diberikan ke siswa mulai dari tingkat SD sampai SMA. Pendidikan ekonomi di Tingkat SD dan SMP terintegral dalam bidang studi IPS dan baru berdiri sendiri mulai tingkat SMA.

Tujuan pendidikan ekonomi adalah dapat membekali siswa untuk mengetahui dan mengerti peristiwa dan masalah ekonomi dalam kehidupan sehari hari terutama yang terjadi di lingkungan individu atau rumah tangga , masyarakat dan negara meningkatkan kemampuan berkompetensi dan bekerjasama dalam masyarakat yang majemuk, baik dalam dalam skala nasional dan internasional. Sedangkan fungsi pendidikan ekonomi adalah untuk mengembangkan kemampuan siswa dalam berekonomi, dengan cara mengenal berbagai kenyataan dari peristiwa ekonomi, memahami konsep dan teori serta berlatih dalam memecahkan masalah ekonomi yang terjadi di lingkungan keluarga.

Namun kenyataanya berbicara lain, fenomena yang terjadi di kalangan siswa menunjukkan bahwa fungsi dan tujuan pendidikan ekonomi yang diajarkan di sekolah tidak terealisasi secara sempurna. Hal ini tampak dari prilaku ekonomi mereka. Konsep konsep dasar ekonomi yang diajarkan di sekolah tidak tampak dalam prilaku kehidupan ekonomi sehari hari mereka. Sebagai contoh, mereka sering belanja barang barang yang tidak ber-

*) Guru SMPN 3 Peterongan Jombang.... 
dasarkan skala prioritas kebutuhan, serta tidak memperhatikan sumber daya keuangan yang mereka miliki, ini menunjukkan bahwa mereka tidak berpikir rasional dalam memanfaatkan sumber daya yang terbatas. Begitu pula saat mereka membeli barang tanpa memperhitungkan cost dan benefit dari pengambilan keputusan untuk belanja. Dari contoh di atas, nampak jelas mereka tidak menerapkan prinsip prinsip ekonomi dalam melakukan tindakan ekonomi seperti yang telah di ajarkan disekolah.

Salemi (2005) menjelaskan bahwa siswa mencapai economic literacy jika mereka dapat menerapkan konsep dasar ekonomi yang terdapat dalam 20 standart NCEE pada tahun tahun kemudian, dalam situasi yang relevan dengan kehidupan mereka dan berbeda dari yang dihadapi di kelas. 20 standart konsep dasar ekonomi itu meliputi: permintaan barang, peran wirausaha, pengaruh tingkat bunga terhadap kecenderungan menabung masyarakat, pendapatan individu, pendapatan nasional, perubahan penawaran dan perubahan permintaan, dampak kebijakan perdagangan internasional, dampak kebijakan pemerintah dalam penetapan harga, peranan pelaku ekonomi (produsen, konsumen dan pemerintah dalam perekonomian), manfaat dari perdagangan internasional, dampak perubahan permintaan/penawaran terhadap harga barang, penggunaan sumber daya yang terbatas, peran pasar modal dalam perekonomian, cost dan benefit dari transaksi ekonomi, mampu menganalisis cost dan benefit dari pengambilan keputusan, peranan pemerintah dalam perekonomian, anggaran pendapatan dan belanja negara, dampak inflasi, mampu menganalisis pengembangan industri, fungsi uang.

Economic literacy sangat penting dalam kehidupan siswa. Dengan economic literacy mereka akan mampu menghadapi permasalahan ekonomi yang relevan dengan kehidupan ekonomi mereka. Di negara negara maju, economic literacy disejajarkan dengan melek huruf. Hal ini menunjukan betapa vitalnya economic literacy bagi seseorang. NCERL (2003) menyebutkan bahwa economic literacy merupakan salah satu keahlian yang harus dimiliki seseorang di abad-21 ini.

Menurut NCREL (2003) seseorang memiliki economic literacy apabila: (1) dapat mengevaluasi biaya, keuntungan dan keterbatasan sumber daya, menggunakan pengetahuan sebagai konsumen, produsen, penyimpan, investor, dan warga negara. (2) mampu untuk mengevaluasi metode yang berbeda untuk menggunakan barang dan jasa dengan mempertimbangkan biaya dan keuntungan dari masing masing metode. (3) dapat mengenal pendorong ekonomi yang mempengaruhi tingkah laku manusia dan menjelaskan bagaimana pengaruh dorongan terhadap tingkah laku mereka. (4) mengerti bagaimana kompetisi, hambatan hambatan perdagangan, kekurangan dan kelebihan, serta interaksi antara pembeli dan penjual dapat mempengaruhi harga. (5) mampu untuk mendeskripsikan peran dari berbagai institusi ekonomi publik dan privat, termasuk bank sentral. (6) mengerti dasar dari pendapatan dan distribusi, tingkat bunga,inflasi, pengangguran, penanaman dan resiko. (7) dapat mengidentifikasi dan mengevaluasi keuntungan dan biaya dari alternatif kebijakan publik dan memperkirakan siapa yang menikmati keuntungan dari menanggung biaya. (7) memahami nilai semangat wirausaha serta peran usaha kecil dan besar dalam perekonomian.

Modernitas siswa merupakan bagian terpenting dalam pengaplikasiain konsep dasar ilmu ekonomi siswa. Hardiman (2003) mengatakan bahwa ada tiga premis sebagai pembentuk jiwa modern yaitu: kesadaran diri akan (hak asasi, otonomi pribadi, demokrasi, fungsi pengetahuan), bersikap kritis dan bersifat progresif.

Salah satu premis modernitas adalah kesadaran diri seseorang terhadap fungsi pen- 
getahuan. Dari sini jelas bahwa siswa yang modern tentunya menyadari bahwa pengetahuan ekonomi yang mereka peroleh dari sekolah adalah mempunyai sebuah fungsi dalam kehidupan mereka, bukan hanya sekedar untuk diketahui tetapi lebih untuk dipraktekkan dalam kehidupan ekonomi. Sikap kritis juga akan mempengaruhi siswa untuk menggali ilmu pengetahuan yang masih abstrak untuk direalitakan dalam kehidupan nyata

Selain modernitas, hasil belajar ekonomi siswa ikut berpengaruh terhadap pengaplikasian konsep dasar ilmu ekonomi. Menurut Mujiono (2006:250) hasil belajar merupakan hasil proses belajar atau proses pembelajaran. Dimana pelaku aktif dalam belajar adalah siswa. Sedangkan pelaku aktif pembelajaran adalah guru. Hasil belajar ekonomi merupakan gambaran tingkat pemahaman pengetahuan siswa terhadap konsep konsep dasar ekonomi yang mereka terima di sekolah. Secara logika tingkat pemahaman pengetahuan yang baik tentang ekonomi akan berpengaruh baik terhadap pengaplikasian dalam kehidupan ekonomi mereka. Sebaliknya, tingkat pemahaman pengetahuan yang kurang baik tentang ekonomi akan berpengaruh kurang baik terhadap pengaplikasian dalam kehidupan ekonomi mereka. Yunus (2010) dalam penelitiannya yang berjudul Economic Literacy amongst the Secondary School Teachers in Perak Malaysia menghasilkan penelitian bahwa pengetahuan ekonomi berpengaruh signifikan terhadap economic literacy.

\section{METODE PENELITIAN}

Berdasarkan tingkat eksplanasinya, penelitian ini termasuk penelitian asosiatif. Karena penelitian ini menghubungkan antar variabel penelitian. Variabel dalam penelitian ini adalah modernitas siswa (X1), hasil belajar ekonomi (X2) dan economic literacy (Y). Populasi dalam penelitian ini adalah siswa kelas IX SMPN 3 Peterongan Jombang tahun pelajaran 2012/2013 yang berjumlah 224 siswa. Sampel yang digunakan dalam penelitian sebesar 144 sisawa dan teknik pengambilan sampel yang digunakan adalah simple random sampling.

Alat yang digunakan untuk mengumpulkan data dalam penelitian ini adalah angket dan daftar nilai. Angket untuk mengukur variabel modernitas siswa dan economic literacy. Skala yang dipakai adalah skala likert yang ditransformasikan menjadi data interval untuk menyusun penilaian rata rata jawaban responden untuk setiap variabel. Adapun daftar nilai digunakan untuk mengukur hassil belajar ekonomi yang berupa daftar nilai ulangan harian ekonomi. Tekhnik analisa data yang digunakan adalah regresi ganda dengan menggunakan rumus sebagai berikut:

$$
\mathrm{Y}=\mathrm{a}+\mathrm{b} 1 \mathrm{X} 1+\mathrm{b} 2 \mathrm{X} 2+\mathrm{ei}
$$

Ada dua uji hipotesis yang digunakan dalam penelitian ini yaitu uji t dan uji F. Uji t digunakan untuk mengetahui ada atau tidaknya pengaruh modernitas siswa (X1) dan hasil belajar ekonomi (X2) secara parsial terhadap economic literacy (Y). Uji F di gunakan untuk mengetahui ada atau tidaknya pengaruh modernitas siswa (X1) dan hasil belajar ekonomi (X2) secara bersama sama terhadap economic literacy (Y).

\section{HASIL PENELITIAN DAN PEMBAHASAN}

\section{Hasil}

1. Kondisi Modernitas siswa

Berdasarkan jawaban responden, kondisi modenitas siswa SMPN 3 Peterongan secara keseluruhan termasuk kategori baik. skor rata rata indikator modernitas siswa yang 
tertinggi adalah kesadaran diri sebagai subyek dan yang terendah adalah bersikap progresif. Secara jelas perolehan skor rata rata indikator modernitas siswa dapat digambarkan dalam gambar 1 berikut.

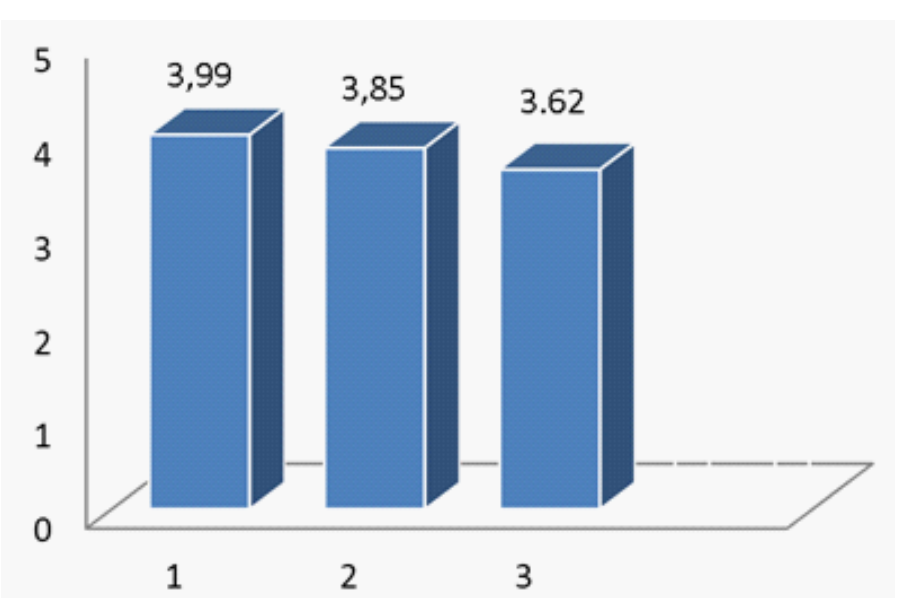

Gambar 1. Diagram kondisi modernitas siswa

Keterangan

$1:$ Kesadaran diri sebagai subyek (masuk dalam kriteria baik)

$2:$ Berpikir kritis (masuk dalam kriteria baik)

3 : Bersikap progresif (masuk dalam kriteria baik)

Tabel 1. Distribusi hasil belajar siswa

\begin{tabular}{|l|l|l|}
\hline Nilai & Jumlah & Prosentase (\%) \\
\hline 50 & 1 & 0.69 \\
\hline 55 & 1 & 0.69 \\
\hline 60 & 1 & 0.69 \\
\hline 70 & 3 & 2.08 \\
\hline 75 & 4 & 2.78 \\
\hline 80 & 11 & 7.64 \\
\hline 81 & 64 & 44.44 \\
\hline 84 & 5 & 3.47 \\
\hline 85 & 18 & 12.50 \\
\hline 86 & 4 & 2.78 \\
\hline 88 & 7 & 4.86 \\
\hline 89 & 2 & 1.39 \\
\hline 90 & 11 & 7.64 \\
\hline 92 & 2 & 1.39 \\
\hline 95 & 6 & 4.17 \\
\hline 96 & 2 & 1.39 \\
\hline 100 & 2 & 1.39 \\
\hline Total & 144 & 100.00 \\
\hline & & \\
\hline
\end{tabular}




\section{Kondisi Hasil Belajar Ekonomi}

Berdasarkan distribusi hasil belajar siswa, sebagian besar siswa SMPN 3 Peterongan sudah memiliki nilai melebihi KKM yaitu sebanyak 123 orang $(85,42 \%)$ sedangkan sisanya yaitu 21 orang $(14,58 \%)$ memiliki nilai dibawah KKM yaitu 81. Distribusi nilai hasil belajar siswa dapat dilihat pada tabel 1.

\section{Kondisi Economic Literacy Siswa}

Berda sarkan distribusi frekuensi variabel penelitian diperoleh hasil bahwa secara keseluruhan kondisi economic literacy siswa SMPN 3 Peterongan termasuk kategori baik. Perolehan skor rata rata indikator economic literacy siswa yang tertinggi adalah pengaplikasian penggunaan sumber daya yang terbatas dan yang terendah adalah pengaplikasian analisa cost dan benifit dalam pengambilan keputusan. Gambaran kondisi indikator economic literacy siswa SMPN 3 Peterongan dapat dilihat dalam diagram 2 di bawah ini.

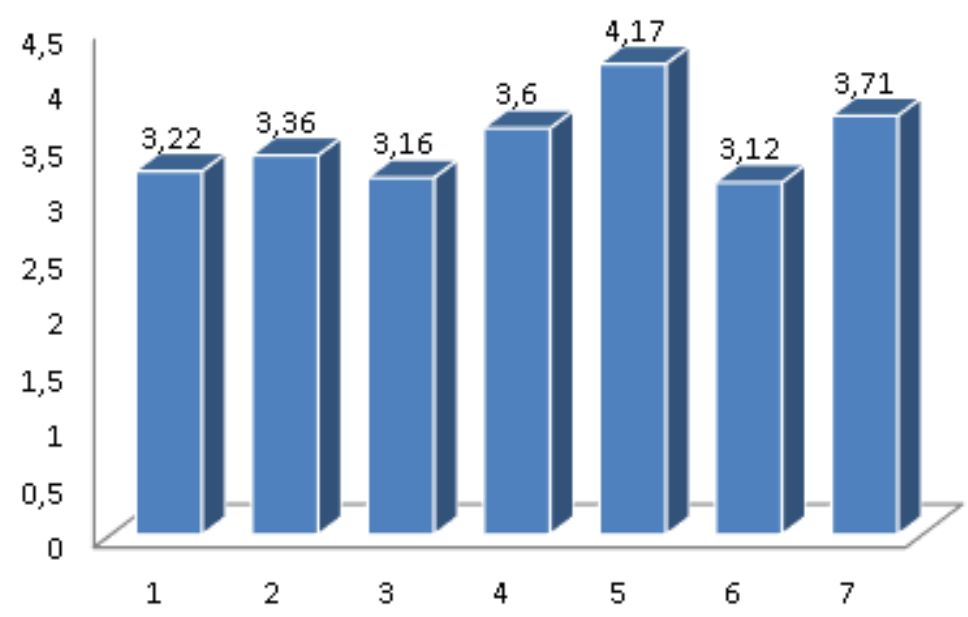

Gambar 2. Skor rata rata indikator

Keterangan

1. Pengaplikasian nilai semangat wirausaha (masuk dalam kriteria baik).

2. Pengaplikasian Perubahan penawaran dan perubahan permintaan (masuk dalam kriteria cukup).

3. Pengapliksian manfaat dari perdagangan internasional (masuk dalam kriteria cukup).

4. Pengaplikasian dampak perubahan permintaan/penawaran terhadap harga barang (masuk dalam kriteria baik).

5. Pengaplikasian penggunaan sumber daya yang terbatas (masuk dalam kriteria baik).

6. Pengaplikasian Analisa cost dan benifit dalam pengambilan keputusan (masuk dalam kriteria cukup).

7. Pengaplikasian fungsi uang (masuk dalam kriteria baik). 


\section{Persamaan Regresi}

Hasil pengolahan data dengan metode regresi linier berganda diperoleh persamaan regresi sebagai berikut :

$$
\mathrm{Y}=25,620+0,665 \mathrm{X} 1-0,065 \mathrm{X} 2+\mathrm{e}_{\mathrm{i}}
$$

Persamaan regresi di atas menjelaskan bahwa :

- Konstanta (a) yang dihasilkan sebesar 25,620 hal ini menunjukkan bahwa besarnya economic literacy (Y) adalah 25,620 jika variabel modernitas (X1) dan hasil belajar ekonomi (X2) adalah konstan.

- Koefisien regresi pada variabel modernitas (X1) adalah positif yaitu sebesar 0,665 artinya jika modernitas (X1) naik satu satuan maka economic literacy (Y) akan naik sebesar 0,665 satuan dengan asumsi variabel hasil belajar ekonomi (X2) adalah konstan.

- Koefisien regresi pada variabel hasil belajar ekonomi (X2) adalah negatif yaitu sebesar -0,065 artinya jika hasil belajar ekonomi (X2) naik satu satuan maka economic literacy (Y) akan turun sebesar 0,065 satuan dengan asumsi variabel modernitas (X1) adalah konstan.

\section{Uji Signifikansi}

Berdasarkan hasil uji t diperoleh hasil bahwa variabel modernitas (X1) secara parsial berpengaruh signifikan terhadap economic literacy $(\mathrm{Y})$, dilihat dari nilai t-hitungnya sebesar 8,140 dengan tingkat signifikan kurang dari 5\% yaitu 0,000. Sedangkan hasil belajar ekonomi (X2) secara parsial berpengaruh tidak signifikan terhadap economic literacy (Y), dilihat dari nilai t-hitungnya sebesar -0,801 dengan tingkat signifikan lebih dari 5\%. Jika dilihat dari nilai r2parsial yaitu 0,3192 pada variabel modernitas (X1) yang berarti besarnya pengaruh modernitas (X1) terhadap economic literacy (Y) adalah 31,92\%. Sedangkan besarnya pengaruh hasil belajar ekonomi (X2) terhadap economic literacy (Y) adalah $0,45 \%$. Hal ini berarti modernitas (X1) lebih dominan pengaruhnya terhadap economic literacy.

Berdasarkan hasil uji $\mathrm{F}$ diperoleh hasil bahwa nilai Fhitung sebesar 33,179 dengan nilai signifikansi sebesar 0,000 kurang dari 5\% sehingga dapat disimpulkan bahwa modernitas (X1) dan hasil belajar ekonomi (X2) secara simultan berpengaruh signifikan terhadap economic literacy $(\mathrm{Y})$.

Berdasarkan hasil uji t dan F maka dengan demikian :

1. Hipotesis yang berbunyi "Diduga ada pengaruh signifikan modernitas siswa terhadap economic literacy siswa" diterima.

2. Hipotesis yang berbunyi "Diduga ada pengaruh signifikan nilai hasil belajar ekonomi terhadap economic literacy siswa" ditolak.

3. Hipotesis yang berbunyi "Diduga ada pengaruh signifikan modernitas dan nilai hasil belajar secara bersama sama terhadap economic literacy siswa" diterima.

\section{Pembahasan}

1. Pengaruh Modernitas Siswa terhadap Economic Literacy

Dalam penelitian ini diperoleh hasil bahwa moderinitas siswa (X1) secara parsial berpengaruh signifikan terhadap economic literacy siswa (Y). Hal ini didasarkan pada 
hasil uji t yaitu nilai t-hitungnya sebesar 8,140 dan tingkat signifikan kurang dari 5\% yaitu 0,000 . Hal ini menunjukkan bahwa semakin tinggi tingkat modernitas siswa maka semakin tinggi economic literacy siswa SMPN 3 Peterongan. Adapun besarnya pengaruh modernitas siswa (X1) terhadap economic literacy adalah 3I.92\%.

Hasil penelitian ini mendukung penelitian yang dilakukan oleh Cunningham (1973) yang menghasilkan penelitian bahwa ada korelasi positif yang kuat antara modernitas siswa dan kinerja akademik siswa. Penelitian ini tidak mendukung penelitian yang dilakukan oleh Ashrafi dan Ghonsooly (2012) yang mengatakan bahwa ada hubungan negatif antara tingkat modernitas dan keberhasilan akademik dalam menerjemahkan teks sastra, ada hubungan negatif antara tingkat modernitas dan keberhasilan akademik dalam menerjemahkan teks politik, yang berarti siswa yang memiliki modernitas yang bagus ternyata tidak mempunyai pengaruh terhadap kemampuan mereka untuk mengaplikasikan ilmu yang sesuai dengan jurusannya.

Tingginya modernitas siswa SMPN 3 Peterongan dapat dilihat dari hasil distribusi frekuensi indikator modernitas. Variabel modernitas siswa meliputi tiga indikator yaitu: kesadaran diri sebagai subyek, bersikap kritis dan bersifat progresif. Secara keseluruhan modernitas siswa SMPN 3 Peterongan termasuk baik dan hasil penelitian ini menunjukan bahwa siswa SMPN 3 Peterongan tingkat modernitasnya tinggi dan berpengaruh terhadap economic literacy siswa.

Kesadaran siswa SMPN 3 Peterongan akan fungsi pengetahuan masuk dalam kategori baik. Hal ini bermakna bahwa seseorang siswa yang memiliki economic literacy yang bagus disebabkan oleh kesadaran mereka akan pentingnya fungsi pengetahuan bagi dirinya sehingga siswa tersebut merasa bahwa ilmu yang diperoleh dari sekolah belum cukup konkret untuk difahami sehingga berupaya untuk mengonkretkan sesuatu yang masih bersifat abstrak dan berupaya memperdalam ilmu pengetahuan melalui berbagai sumber baik dari buku/koran/tv maupun media internet. Dalam era globalisasi saat ini, tidak dapat dipungkiri hampir $95 \%$ siswa SMPN 3 Peterongan menggakses informasi lewat internet. Siswa lebih tertarik untuk mencari sesuatu informasi pengetahuan lewat internet karena memang dirasa lebih lengkap dan lebih mudah untuk difahami karena tersedia contoh contoh yang nyata dari kehidupan, selain itu hanya dengan mengklik apa yang diinginkan akan muncul dan tersedia berbagai bahan bahan pembelajaran yang membantu mereka untuk mempermudah memahami dan mengaplikasikan ilmu pengetahuan yang diperoleh dari sekolah.

Sikap kritis siswa SMPN 3 Peterongan masuk dalam kategori baik. Hal ini berarti bahwa siswa SMPN 3 Peterongan saat mengakses ilmu pengetahuan dari koran/buku/tv maupun internert, sementara mereka menemukan sesuatu yang kurang difahami atau tidak sesuai dengan pola pikir mereka maka siswa tersebut akan mendiskusikannya dengan orang yang lebih pintar, selain itu siswa SMPN 3 Peterongan tidak menerima begitu saja ilmu pengetahuan yang ia peroleh dari bapak/ibu guru tetapi berupaya untuk menanyakan dan mencari jawaban terhadap hal hal yang menimbulkan tanda tanya dalam benak pemikiran mereka sehingga siswa yang memiliki sikap kritis saat proses pembelajaran maka akan meningkatkan economic literacy. Sikap kritis siswa saat pembelajaran sangat penting, karena dengan sikap kritis tersebut siswa tidak hanya sekedar tahu tapi faham yang pada gilirinnya akan memudahkan siswa dalam menerapkan ilmu tersebut.

Sifat progresif siswa SMPN 3 peterongan juga masuk dalam kategori baik. Hal ini berarti siswa SMPN 3 Peterongan berupaya untuk menguasai teknologi informasi melalui 
internet untuk kepentingan pendidikannya. Dengan penguasaan teknologi internet mereka akan mudah untuk mengerjakan tugas tugas dari guru sehingga tugas yang dihasilkannya akan menjadi lebih baik.

Dari uraian di atas dapat dikatakan bahwa sesorang siswa yang memiliki tingkat modernitas yang tinggi yang di tandai dengan kesadaran diri sebagai subyek ( baik dalam hal hak asasi, otonomi pribadi, fungsi pengetahuan dan demokrasi), bersikap kritis dan bersifat progresif maka economic literacynya akan tinggi pula, dalam arti siswa yang memiliki tingkat modernitas yang tinggi akan menjadikan siswa memiliki kemampuan untuk mengaplikasikan konsep dasar ilmu ekonomi seperti : pada saat ada penawaran dengan harga murah dan kebetulan ia membutuhkannya maka ia akan membeli barang tersebut, mengurangi jumlah buku tulis pada saat harga bulpen mengalami kenaikan, mengkonsumsi buah import selama harganya murah, membeli HP/Lap Top/Alfa Link produk luar negeri selamanya kualitasnya lebih unggul dibanding produk dalam negeri, mengurangi jumlah barang yang dibeli pada saat harganya naik dan sebaliknya menambah jumlah barang yang dibeli pada saat harganya naik, mengutamakan membeli barang yang sesuai dengan skala prioritas, membeli alat tulis dikopsis untuk mendukung pengembangan usaha kopsis dan bila ada sisa uang saku maka akan ditabung.

\section{Pengaruh Hasil Belajar Ekonomi terhadap Economic Literacy}

Berdasarkan hasil penelitian ini menunjukkan bahwa hasil belajar ekonomi (X2) secara parsial berpengaruh tidak signifikan terhadap economic literacy $(\mathrm{Y})$, dilihat dari nilai t-hitungnya sebesar -0,801 dengan tingkat signifikan lebih dari 5\%. Hasil ini menunjukan bahwa hasil belajar ekonomi yang baik tidak berpengaruh pada economic literacy yang baik pula, artinya seorang siswa yang hasil belajar ekonominya bagus tidak bisa dijadikan dasar bahwa economic literacy juga bagus.

Hasil penelitian ini mendukung penelitian yang dilaksanakan oleh Shypley dan Shetty (2008) dalam penelitian yang berjudul Factors Affecting Economic Literacy of College Student: Some Aditional Evidence menghasilkan penelitian bahwa tidak ada perbedaaan signifikan antara hasil test economic literacy mahasiswa jurusan pendidikan dasar dengan mahasiswa jurusan bisnis. Dari sini nampak jelas bahwa jurusan pendidikan dasar tidak punya bekal tentang ilmu ekonomi bila dibandingkan dengan jurusan bisnis yang berbekal ilmu ekonomi, ternyata hasil tes economic literacynya tidak ada perbedaan yang signifikan.

Saat ini kita tidak bisa menutup mata, terhadap fenomena fenomena yang terjadi dalam dunia pendidikan bahwa hasil belajar peserta didik tidak mencerminkan hasil belajar yang sesungguhnya, artinya hasil belajar sebagai pencerminan penguasaan kompetensi dasar tidak selaras dengan pengaplikasian dalam kehidupan sehari hari.

Ada beberapa alasan mengapa hasil belajar tidak dapat di transfer dalam penggunaan yang aktual. Pertama, selama ini guru dalam mengajar sebenarnya sudah memiliki perangkat pembelajaran yang lengkap dan bagus, namun saat proses pembelajaran masih sering menekankan transfer pengetahuan yang bersifat informatif sehingga intrumen tes yang terbentuk hanya mencerminkan taraf berfikir tingkat satu dan dua yaitu ingatan dan pemahaman, padahal pada jenjang pendidikan menengah pertama (SMP/MTs) seharusnya penekanan tingkat kemampuan berfikir mulai dari kemampuan ingatan, pemahaman, aplikasi dan analisis. Kondisi ini pada akhirnya menyebabkan siswa hanya mampu mengungkapkan kata kata yang dihafalkan dari buku pelajarannya tetapi tidak dapat meng- 
gunakannya dalam situasi baru.

Uraian di atas sejalan dengan pendapat Arifin (2011:71) yang mengatakan bahwa "apabila suatu hasil belajar tidak dapat ditransfer dan hanya dapat digunakan dalam situasi tertentu saja, maka hasil belajar itu disebut hasil belajar palsu. Sebaliknya, jika suatu hasil belajar dapat ditransfer kepada penggunaan yang aktual, maka hasil belajar itu disebut hasil belajar autentik . Jadi, evaluasi yang baik harus mengukur hasil belajar yang autentik dan kemungkinan dapat ditransfer".

Lebih lanjut Arifin (2011: 71) menegaskan bahwa "dalam penelitian sering ditemui hasil belajar yang dicapai tampaknya baik, tetapi sebenarnya hasil belajar itu palsu. Peserta didik hanya dapat mengucapkan kata kata yang dihafalkan dari buku pelajaranya, tetapi mereka tidak dapat menggunakannya dalam situasi baru. Penguasaan matapelajaran seperti ini tidak lebih dari penguasaan beo, yang pada akhirnya peserta didik hanya memiliki pengetahuan yang bersifat informatif, belum tentu menjamin pemahaman dan pengertiannya untuk di aplikasikan dalam kehidupan".

Kedua, dilihat dari segi siswa, selama ini siswa tidak memahami makna dari suatu nilai hasil belajar, mereka menganggap bahwa dengan nilai yang bagus mereka adalah anak pandai dalam tanda kutip. Anggapan seperti ini memang tidak selamanya salah, karena memang selama ini sekolah lebih mengedapankan nilai hasil belajar yang memenuhi standar KKM tanpa memperhatikan apakah nilai itu sudah mencerminkan kemampuan siswa untuk mentransfer ilmu pengetahuan yang mereka terima dari sekolah dalam situasi yang fungsional. Sehingga sering ditemukan dilapangan siswa berupaya untuk mendapatkan nilai yang bagus melalui jalan mencontek dan bekerjasama dengan teman demi mendapatkan nilai bagus dan pada akhirnya nilai bagus yang ia peroleh tidak bisa mencerminkan kemampuan mereka sesungguhnya serta tidak berpengaruh terhadap kemampuan mereka untuk mengaplikasikan konsep dasar ilmu ekonomi yang mereka terima dari sekolah.

Dari uraian di atas mengandung arti bahwa hasil belajar ekonomi siswa yang bagus tidak menjamin bahwa siswa tersebut mampu mengaplikasikan prilaku prilaku seperti ini: pada saat ada penawaran dengan harga murah dan kebetulan ia membutuhkannya maka ia akan membeli barang tersebut, mengurangi jumlah buku tulis pada saat harga bulpen mengalami kenaikan, mengkonsumsi buah import selama harganya murah, membeli HP/Lap Top/Alfa Link produk luar negeri selamanya kualitasnya lebih unggul dibanding produk dalam negeri, mengurangi jumlah barang yang dibeli pada saat harganya naik dan sebaliknya menambah jumlah barang yang dibeli pada saat harganya naik, mengutamakan membeli barang yang sesuai dengan skala prioritas, membeli alat tulis dikopsis untuk mendukung pengembangan usaha kopsis dan bila ada sisa uang saku maka akan ditabung.

Fenomena di atas merupakan beberapa penyebab mengapa seseorang yang hasil belajarnya bagus tetapi tidak bisa dijadikan jaminan bahwa seorang siswa dengan hasil belajar yang baik mampu mengaplikasikan dalam situasi yang relevan dengan kehidupannya.

\section{Pengaruh Modernitas Siswa dan Hasil Belajar Ekonomi terhadap Economic Literacy.}

Berdasarkan hasil uji secara simultan menunjukkan bahwa peningkatan modernitas dan hasil belajar berpengaruh signifikan terhadap peningkatan economic literacy siswa. Hasil penelitian ini terlihat nilai Fhitung sebesar 33,179 dengan nilai signifikansi sebesar 0,000 kurang dari 5\% sehingga dapat disimpulkan bahwa modernitas (X1) dan hasil belajar ekonomi (X2) secara simultan berpengaruh signifikan terhadap economic literacy (Y). Besarnya pengaruh modernitas (X1) dan hasil belajar ekonomi (X2) secara simultan ter- 
hadap economic literacy (Y) sebesar 32\% sedangkan 68\% dipengaruhi oleh faktor-faktor lain selain variabel modernitas siswa dan hasil belajar.

Hasil belajar merupakan pencerminan penguasaan kompetensi dasar suatu mata pelajaran maka akan berpengaruh terhadap kemampuan siswa untuk mengaplikasikan penguasaan apa yang ia pahami tentang ilmu pengetahuan yang telah ia peroleh dari sekolah dalam kehidupan sehari harinya. Begitu halnya dengan hasil belajar ekonomi, jika siswa memahami tentang konsep dasar ilmu ekonomi maka setidak tidaknya dengan bekal ilmu ekonomi yang ia terima dari sekolah akan mempunyai kemampuan untuk mengaplikasikannya sesuai dengan konsep ilmu ekonomi yang ia terima, semakin paham tentang konsep ilmu ekonomi maka semakin mampu ia mengaplikasikannya dalam situasi yang relevan dengan kehidupannya.

Hal ini sejalan dengan Hasil penelitian yang dilakukan oleh : (1) Purwati (2011) yang menghasilkan penelitian bahwa prestasi belajar ekonomi berpengaruh secara signifikan terhadap prilaku konsumsi siswa, (2) Yunus (2010) menyimpulkan bahwa: pengetahuan ekonomi berpengaruh secara signifikan dengan economic literacy, (3) Wood and Doyle (2002) menyimpulkan bahwa variabel pendidikan berpengaruh signifikan terhadap economic literacy, (4) Lavoie dan Gill (2009) dalam penelitiannya yang berjudul A Study of High School Economic Literacy in Orange County, California. Menghasilkan penelitian bahwa Setelah satu semester menerima pembelajaran ekonomi, skor tes economic literacy siswa SMA Orange County California naik sebesar 12,3 poin dan prestasi akademik meningkatkan skor post tes, mengendalikan perbedaan dalam skor pre tes.

Sementara itu, pengaruh signifikan modernitas siswa terhadap economic literacy dalam penelitian ini mendukung penelitian yang dilakukan oleh Cunningham (1973) yang menghasilkan penelitian bahwa ada korelasi positif yang kuat antara modernitas siswa dan kinerja akademik siswa. Hal ini dapat di artikan bahwa seorang siswa yang memiliki modernitas tinggi maka ia akan memiliki kemampuan untuk mempraktekkan ilmunya.

Dari penelitian tentang modernitas dan hasil belajar di atas dapat di jadikan landasan bahwa variabel modernitas siswa dan hasil belajar ekonomi berpengaruh secara signifikan terhadap economic literacy siswa. Dengan demikian hasil belajar yang didukung oleh modernitas siswa yang tinggi akan menjadikan siswa mampu untuk mengaplikasikan konsep konsep dasar ilmu ekonomi yang mereka terima di sekolah, antara lain kemampuan untuk memanfaatkan sisa uang saku sebagai tabungan dan membelanjakan uang saku berdasarkan skala prioritas kebutuhan.

\section{KESIMPULAN}

Berdasarkan hasil penelitian dan pembahasan dapat dikemukakan kesimpulan sebagai berikut: (1) ada pengaruh signifikan modernitas siswa terhadap economic litercy siswa SMPN 3 Peterongan, yang berarti semakin tinggi modernitas siswa semakin tinggi pula cenomic literacy siswa SMPN 3 peterongan, (2) tidak ada pengaruh signifikan hasil belajar ekonomi terhadap economic literacy siswa SMPN 3 peterongan, yang berarti kenaikan hasil belajar ekonomi tidak berpengaruh terhadap naiknya economic literacy siswa SMPN 3 peterongan, (3) Ada pengaruh signifikan modernitas siswa dan hasil belajar ekonomi secara bersama sama terhadap economic literacy siswa SMPN 3 Peterongan, yang berarti semakin tinggi modernitas siswa dan hasil belajar ekonomi maka semakin tinggi economic litercy siswa SMPN 3 Peterongan. 
Berdasarkan hasil penelitian ini, diketahui bahwa modernitas siswa berpengaruh terhadap economic literacy maka sebaiknya premis modernitas seperti kesadaran diri akan fungsi pengetahuan, sikap kritis dan sifat progresif di jadikan sebagai salah satu aspek penilaian prilaku berkarakter yang muncul dalam RPP dan benar benar di realisasikan saat proses pembelajaran.

Agar hasil belajar ekonomi penuh makna dan autentik, dalam arti hasil belajar dapat di transfer kepada penggunaan yang aktual, maka ada beberapa cara yang bisa dilakukan oleh bapak/ibu guru :

a. learning by doing (belajar sambil mengerjakan)

Belajar materi ilmu ekonomi sambil mempraktekkan materi tersebut. Misal: 1) Saat mengajarkan materi skala prioritas, siswa langsung di beri pengalaman untuk menyusun skala prioritas kebutuhan dan ada kewajiban untuk membelanjakan uang saku berdasarkan skala prioritas yang telah di susun. 2) Saat mengajarkan materi fungsi uang, siswa di minta untuk mempraktekkan salah satu fungsi uang dengan cara menyisahkan uang saku dan di tabung lewat bendahara kelas.

b. Peningkatan kualitas instrumen ulangan harian

Dalam menyusun soal ulangan harian lebih ditingkatkan pada kemampuan aplikasi/ penerapan $(\mathrm{C} 3)$ dan kemampuan analisis $(\mathrm{C} 4)$ sehingga siswa tidak hanya sekedar hafal dari buku pelajaran.

Sekolah sebaiknya tidak hanya mengedapankan hasil belajar yang bagus tetapi lebih mengedapankan hasil belajar yang autentik dengan cara menghimbau kepada semua guru untuk mengadakan evaluasi hasil belajar yang menjamin bahwa hasil belajar tersebut dapat di aplikasikan dalam penggunaan yang aktual.

Adanya pengaruh secara bersama sama antara modernitas siswa dan hasil belajar ekonomi sebesar $32 \%$, yang berarti masih ada variabel lain yang berpengaruh terhadap economic literacy sebesar 68\%, maka disarankan bagi peneliti lain mengadakan penelitian terhadap variabel lain selain variabel modernitas siswa dan hasil belajar ekonomi. Seperti latar belakang pendidikan orang tua, pendidikan ekonomi dalam keluarga, sistem evaluasi hasil belajar.

\section{DAFTAR RUJUKAN}

Arifin, Zainal. 2011. Evaluasi pembelajaran. Bandung: Remaja Rosdakarya

Ashrafi, Nasrin dan Ghonsooly, Behzad. 2012. The Interface of Tradition and Modernity: Ideological Manipulation of Translators . Journal of Educational and Social Research. Vol. 2 (3) September 2012. (online), (http://www3.ul.ie/sociology/socheolas/vol4/1/Introduction.pdf) ), di akses 29 Januari 2012.

Cunningham, Ineke. 1973. The relationship between Modernity of Students in their Academic Performace, Peers and Parents. International journal of Comparative sociology. September 1973 14:203-220. (online), (http;//cos.sagepub.com/content/14/3-4/203full. pdf), di akses 20 Januari 2013. 
Dimyati dan Mudjiono. 2006. Belajar dan Pembelajaran. Jakarta: Rineka Cipta.

Hardiman, Budi. 2003. Melampaui Positivisme dan Modernitas. Yogyakarta: Kanisius.

Hasan, M. Iqbal. 2002. Pokok Pokok Materi Metodelogi Penelitian dan Aplikasinya. Jakarta : Ghalia Indonesia.

Lavoi and Gill Andrew. 2009. A Study of High School Economic literacy in Orange County California. Eastern Economic journal, 35,433-451.

Michael K. Salemi. 2005. Teaching Economic literacy: What, Why and How. Journal International Review of Economics Education, volume 4, issue 2 (2005), pp. 46-57. (online), http://www.economicsnetwork.ac.uk/iree/v4n2/salemi.htm, di akses 17 Juni 2012.

NCREL. 2003. EnGauge 21 st Century Skill: literacy in the Digital Age. (online), (www. ncrel.org/engauge), diakses, tanggal 13 juni 2012

Purwati, Ana. Pengaruh Status Sosial Ekonomi Orang Tua, Persepsi atas Lingkungan, dan Prestasi Belajar Ekonomi terhadap prilaku Konsumsi. Jurnal Ekonomi Bisnis. Th16. NO.1, Maret 2011. (online), (http://fe.ac..id/wp-content), di akses 24 agustus 2012.

Sugiyono. 2003. Metode Penelitian Administrasi. Bandung: Alfabeta

Shipley, Calvin and Shetty, Shekar. Factors Affecting Economic Literacy of College Student: Some Additional Evidence. Journal of Economic and Economic Education Research, Vol. 9, Number 1, 2008

Wood, W., C. \& Doyle, J., M. (2002). Economic literacy among Corporate Employees. Journal of Economic Education. 195-205. (online), (http://130.203.133.150/view doc/ summary), di akses 29 Agustus 2012

Yunus, Nek Kamal Yeop. 2010. Economic Literacy amongs the Secondary School Teachers in Perak Malaysia. Journal Information Management and Business Review. Vol. 1, No. 2, pp. 69-78. (online), (http://www.ifrnd.org ), di akses 25 Agustus 2012 